\title{
Strategi Pengembangan Usaha Mikro Kecil Menengah (UMKM) Berbasis Ekonomi Kreatif di Kecamatan Puloampel Kabupaten Serang Banten
}

\author{
Ulfi Jefri ${ }^{a}$, Ibrohim ${ }^{b}$ \\ aUniversitas Bina Bangsa, ulfijefri.binabangsa@gmail.com \\ bUniversitas Bina Bangsa, ibrohim.binabangsa@gmail.com
}

\begin{abstract}
A b s t r a k
Kecamatan Pulo Ampel memiliki potensi produk Usaha Mikro Kecil Menengah (UMKM) yang berbasis ekonomi kreatif yang perlu untuk di kembangkan, mulai dari hasil laut, perikanan, pertanian, kerajinan tangan, peternakan, makanan. Tujuan penelitian ini adalah untuk mengkaji dan menganalisa strategi pengembangan Usaha Mikro Kecil dan Menengah (UMKM) berbasis ekonomi kreatif di Kecamatan Pulo Ampel Kabupaten Serang Banten. Metode yang digunakan adalah metode kualitatif melalui proses observasi, wawancara dan dokumentasi, dengan analisis Matrik SWOT untuk mengetahui kekuatan, kelemahan, peluang dan ancaman dalam rangka pengembangan UMKM berbasis ekonomi kreatif di Kecamatan Pulo Ampel Serang Banten. Informan yang dijadikan sumber data terdiri dari: Camat Pulo Ampel, Kepala Desa yang ada di Kecamatan Pulo Ampel, Pihak akademisi, pelaku UMKM, Pegawai Dinas UMKM Serang, pengamat UMKM, penelitian dilakukan selama kurun waktu satu tahun. Sedangkan strategi yang tepat dilakukan dalam pengembangan Usaha Mikro Kecil Menengah (UMKM) yang ada di Kecamatan Puloampel Kabupaten Serang adalah strategi adalah Strategi SO (Growth).Strategi SO merupakan strategi yang memanfaatkan kekuatan yang ada untuk meningkatkan keunggulan kompetitifnya.Hasil dari penelitian ini menunjukan para pelaku UMKM yang berbasis ekonomi kreatif belum mampu memberikan predikat khusus bagi Kecamatan Pulo Ampel, karena mereka memiliki kemampuan yang terbatas serta mengalami permasalahan dalam pengembangan usahanya.Beberapa permasalahan yang dihadapi UMKM kreatif Kecamatan Pulo Ampel antara lain permasalahan permodalan yang terbatas, bahan baku dan penggunaan peralatan produksi yang sederhana, media pemasaran terbatas karena belum adanya sentra UMKM, biaya transaksi yang cukup banyak, tenaga kerja yang kurang terampil, dan masalah pendaftaran hak cipta mereka.
\end{abstract}

Kata Kunci: Pengembangan, UMKM, Ekonomi Kreatif.

\section{A b s t r a c t}

Pulo Ampel District has the potential for products of Micro, Small and Medium Enterprises (MSMEs) based on creative economy that need to be developed, ranging from marine products, fisheries, agriculture, handicrafts, animal husbandry, food. The purpose of this research are to study and to analyze development strategies. Micro, Small and Medium Enterprises (MSMEs) based on creative economy in Pulo Ampel District, Serang Regency, Banten. The study used a qualitative method through a process of observation, interviews and documentation, with a SWOT matrix analysis to determine the strengths, weaknesses, opportunities and threats in the development of creative economy-based MSMEs in Pulo Ampel District Serang Banten. Informants who were used as data sources consisted of: Head of Pulo Ampel Sub-district, Village Heads in Pulo Ampel District, academics, MSME actors, Serang MSMEs Service Employees, MSMEs observers. This study was carried out over a period of one year. Meanwhile, While the right strategy for developing Micro, Small and Medium Enterprises (MSMEs) in Puloampel District, Serang Regency is the SO (Growth) Strategy. The SO Strategy is a strategy that utilizes existing strengths to increase its competitive advantage. MSME actors based on the creative economy have not been able to give a special predicate to Pulo Ampel District, because they 
have limited capabilities and experience problems in developing their business. Some of the problems faced by creative MSMEs in Pulo Ampel District include limited capital, raw materials and use of equipment simple production, limited marketing media due to the absence of MSME centers, high transaction costs, unskilled labor, and problems registering their copyright.

Keywords: Development, MSMEs, creative economy.

\section{Pendahuluan}

Indonesia telah mengalami dampak Covid-19 yang menyebabkan jatuhnya perekonomian nasional. Banyak usaha-usaha skala besar pada berbagai sektor termasuk industri, perdagangan, dan jasa yang mengalami stagnasi bahkan sampai terhenti aktifitasnya pada bulan Maret, April, Mei, Juni, dengan diberlakukannya Work From Home (WFH). Namun, Usaha Mikro, Kecil, dan Menengah (UMKM) dapat bertahan dan menjadi pemulih perekonomian di tengah keterpurukan akibat covid-19 pada berbagai sektor ekonomi.

Kegiatan Usaha Mikro Kecil dan Menengah (UMKM) merupakan salah satu bidang usaha yang dapat berkembang dan konsisten dalam perekonomian nasional. UMKM menjadi wadah yang baik bagi penciptaan lapangan pekerjaan yang produktif. UMKM merupakan usaha yang bersifat padat karya, tidak membutuhkan persyaratan tertentu seperti tingkat pendidikan, keahlian (keterampilan) pekerja, dan penggunaan modal usaha relatif sedikit serta teknologi yang digunakan cenderung sederhana. UMKM masih memegang peranan penting dalam perbaikan perekonomian Indonesia, baik ditinjau dari segi jumlah usaha, segi penciptaan lapangan kerja, maupun dari segi pertumbuhan ekonomi nasional yang diukur dengan Produk Domestik Bruto.

UMKM mempunyai peranan strategis dalam pembangunan ekonomi nasional. UMKM berperan dalam pertumbuhan ekonomi dan penyerapan tenaga kerja. Selain itu, UMKM juga berperan dalam pendistribusian hasil-hasil pembangunan. Keberadaan sektor UMKM bukan hanya dianggap sebagai tempat penampungan sementara bagi para pekerja yang belum masuk ke sektor formal, tetapi juga sebagai motor pertumbuhan aktivitas ekonomi. Hal ini dikarenakan jumlah penyerapan tenaga kerjanya yang demikian besar. Mengingat pengalaman yang telah dihadapi oleh Indonesia selama krisis ekonomi, kiranya tidak berlebihan apabila pengembangan sektor swasta difokuskan pada UMKM.

Kementerian Koperasi dan UMKM (2012) menyebutkan usaha Mikro, Kecil, dan Menengah (UMKM) yang berkembang saat ini terbagi menjadi beberapa kategori yaitu pertanian, peternakan, perikanan, kehutanan, listrik, gas, air bersih, perdagangan, hotel, restoran, jasa-jasa swasta, dan industri pengolahan yang salah satunya mencakup industri kreatif. Sektor industri kreatif diyakini mampu bertahan ketika berbagai sektor lain dilanda krisis keuangan global. Pemerintah mulai melirik industri kreatif sebagai alternatif roda penggerak ekonomi yang akan terus berputar. Industri kreatif meliputi 14 subsektor, yaitu periklanan, arsitektur, pasar barang seni, kerajinan, desain, busana, video, film, dan fotografi, permainan interaktif, musik, seni pertunjukan, penerbitan dan 4 percetakan, layanan komputer dan peranti lunak, televisi dan radio, serta riset dan pengembangannya. 
Departemen Perdagangan (2008) menyebutkan industri kreatif adalah bagian tak terpisahkan dari ekonomi kreatif. Ekonomi kreatif dapat dikatakan sebagai sistem transaksi penawaran dan permintaan yang bersumber pada kegiatan ekonomi yang digerakkan oleh sektor industri yang disebut industri kreatif. Pemerintah menyadari bahwa ekonomi kreatif yang berfokus pada penciptaan barang dan jasa dengan mengandalkan keahlian, bakat, dan kreativitas sebagai kekayaan intelektual adalah harapan bagi ekonomi Indonesia untuk bangkit, bersaing, dan meraih keunggulan dalam ekonomi global.

Industri kreatif perlu dikembangkan di Indonesia karena memiliki peranan penting dalam pengembangan ekonomi negara dan daerah (Departemen Perdagangan, 2008). Pertama, sektor industri kreatif memberikan kontribusi ekonomi yang signifikan seperti peningkatan lapangan pekerjaan, peningkatan ekspor, dan sumbangannya terhadap PDB. Kedua, menciptakan Iklim bisnis positif yang berdampak pada sektor lain. Ketiga, membangun citra dan identitas bangsa seperti turisme, ikon Nasional, membangun budaya, warisan budaya, dan 5 nilai lokal. Keempat, berbasis kepada Sumber Daya yang terbarukan seperti ilmu pengetahuan dan peningkatan kreatifitas. Kelima, menciptakan inovasi dan kreativitas yang merupakan keunggulan kompetitif suatu bangsa. Terakhir, dapat memberikan dampak sosial yang positif seperti peningkatan kualitas hidup dan toleransi sosial.

Kecamatan Pulau Ampel merupakan daerah kecamatan bagian dari wilyah Kabupaten Serang Provinsi Banten.Dimana Kecamatan Pulo Ampel terletak di pesisir pantai utara pulau jawa yang memiliki beberapa desa diantaranya: Argawana, Banyuwangi, Gedung Soka, Mangunreja, Margasari, Pulo Ampel, Pulau Panjang, Salira, dan Sumuranja. Kecamatan Pulau Ampel memiliki potensi produk UMKM yang perlu untuk di kembangkan, mulai dari hasil perkebunan, perikanan, pertanian, kerajinan tangan, peternakan ,makanan, dan lain sebagainya.Namun selama ini masyarakat Kecamatan Pulo Ampel mulai aparat kecamatan, aparat desa, para pelaku UMKM, dan lain sebagainya belum bisa mengembangkan produk hasil olahan mereka, belum bisa menciptakan produk khas lokal yang terbentuk melalui produk-produk UMKM mereka.Hal ini menyebabkan Kecamatan Pulo Ampel mengalami ketertinggalan dalam pengembangan UMKM dengan Kecamatan-kecamatan yang ada di Kabupaten Serang.

Tabel 1

Daftar Nama Produk UMKM Kecamatan Pulo Ampel

\begin{tabular}{|l|l|l|l|}
\hline No. & \multicolumn{1}{|c|}{ Nama Desa } & \multicolumn{1}{|c|}{ Produk UMKM } & \multicolumn{1}{c|}{ Keterangan } \\
\hline 1 & Argawana & Keripik pisang & Industri Produktif \\
\hline 2 & Banyuwangi & Debontot, olahan makanan dari ikan & Industri Produktif \\
\hline 3. & Gedung soka & Kerajinan Gerabah, & Industri Kreatif \\
\hline 4. & Mangunreja & Kue Gipang, Kerupuk Udang & Industri Produktif \\
\hline 5 & Margasari & Emping, Kerupuk Ikan Payus & Industri Produktif \\
\hline 6. & Pulo Ampel & Tempe \& Tahu, olahan ikan asin & Industri Produktif \\
\hline 7 & Pulau Panjang & Dola-dola rumput laut & Industri Produktif \\
\hline
\end{tabular}




\begin{tabular}{|l|l|l|l|}
\hline 8 & Salira & Kerajinan Kulit kerang, Bonsai Kelapa & Industri Kreatif \\
\hline 9. & Sumuranja & Ranginang Beras Ketan & Industri Produktif \\
\hline
\end{tabular}

Sumber: data Kecamatan Pulo Ampel Serang 2020

Permasalahan UMKM berbasis ekonomi kreatif pada umumnya terletak pada : sumber daya manusia, modal, pemasaran dan penguasan teknologi informasi, masih banyak masyarakat Kecamatan Pulo Ampel yang belum mau menjadi wirausaha, belum adanya Badan Usaha Milik Desa (BUMDES) di setiap desa yang ada di Kecamatan Pulo Ampel yang mampu mengolah, menampung dan memasarkan produk hasil olahan UMKM di Kecamatan Pulo Ampel.Gambaran kondisi potensi UMKM yang ada di Kecamatan Pulo Ampel berbasis ekonomi kreatif pada saat ini, dilihat dari peluang pemberdayaan dari waktu ke waktu, dari tempat ke tempat, dan dari sektor ke sektor belum mengindikasikan besarnya harapan pada kelompok usaha tersebut untuk mendukung tumbuhnya sistem perekonomian yang berkeadilan. Hal ini juga mengakibatkan UMKM berbasis ekonomi kreatif belum mampu memberikan suatu ciri khas khusus bagi Kecamatan Pulo Ampel dikenal oleh masyarakat umum baik di dalam maupun luar kecamatan Pulo Ampel itu sendiri.

Hasil temuan penelitian Dani Danuar Tri Darwanto (2013) menunjukan bahwa UMKM kreatif belum mampu memberikan predikat khusus bagi Kota Semarang karena mereka memiliki kemampuan yang terbatas serta mengalami permasalahan dalam pengembangan usahanya. Beberapa permasalahan yang dihadapi UMKM kreatif kota Semarang antara lain permasalahan permodalan yang terbatas, bahan baku dan penggunaan peralatan produksi yang sederhana, media pemasaran terbatas karena belum adanya sentra UMKM, biaya transaksi yang cukup banyak, tenaga kerja yang kurang terampil, dan masalah pendaftaran hak cipta mereka. Dengan adanya permasalahan tersebut, maka pengembangan UMKM berbasis ekonomi kreatif perlu mendapatkan perhatian yang besar baik dari pemerintah atau dinas terkait maupun masyarakat agar dapat berkembang lebih kompetitif bersama pelaku ekonomi lainnya. Kebijakan pemerintah ke depan perlu diupayakan lebih kondusif bagi tumbuh dan berkembangnya UMKM. Pemerintah perlu meningkatkan perannya dalam memberdayakan UMKM berbasis ekonomi kreatif karena seperti yang telah dijelaskan sebelumnya, UMKM berbasis ekonomi kreatif memiliki peranan yang penting dalam pengembangan ekonomi negara dan daerah. Bagaimanakah penerapan strategi pengembangan UMKM di Kecamatan Pulo Ampel Kabupaten Serang Bnaten.Tujuan penelitian untuk mengkaji dan menganalisa strategi pengembangan UMKM berbasis ekonomi kreatif di Kecamatan Pulo Ampel Kabupaten Serang Banten.

\section{Landasan Teori}

\subsection{Usaha Mkro Kecil dan Menengah (UMKM)}

Sektor UMKM merupakan salah satu kekuatan utama dan vital yang mampu pendorong pembangunan ekonomi dan lapangan pekerjaan (Supardi et al., 2021). Menurut Sugiyanto et al., (2021) bahwa UMKM merupakan salah satu sektor yang mempunyai peranan penting dalam pembangunan ekonomi. Menurut Pakpahan (2020); Alfrian \& Pitaloka 
(2020), bahwa berdasarkan pengalaman yang terjadi pada kurun waktu 1998 hingga 2012 membuktikan bahwa UMKM ternyata mampu bertahan dari krisis ekonomi, ditunjukkan dengan pertumbuhan positif yang dicapai UMKM. Usaha Mikro, Kecil dan Menengah (UMKM) memiliki peranan penting dan strategis dalam perekonomian di Indonesia. Peran penting UMKM tidak hanya berarti bagi pertumbuhan di kota - kota besar tetapi berarti juga bagi pertumbuhan ekonomi di pedesaan (Hamid \& Ikbal, 2017). Menurut bahwa Amri (2020), UMKM merupakan jenis usaha yang memiliki peran penting dalam peningkatan PDB (Pendapatan Domestik Bruto) satu negara khususnya di Indonesia.

Berdasarkan Undang-Undang nomor 20 tahun 2008 tentang Usaha Mikro, Kecil, dan Menengah, UMKM didefinisikan sebagai berikut:

a. Usaha mikro adalah usaha produktif milik orang perorangan dan/atau badan usaha perorangan yang memenuhi kriteria Usaha Mikro sebagaimana diatur dalam UndangUndang ini.

b. Usaha Kecil adalah usaha ekonomi produktif yang berdiri sendiri, yang dilakukan oleh orang perorangan atau badan usaha yang bukan merupakan anak perusahaan atau bukan cabang perusahaan yang dimiliki, dikuasai, atau menjadi bagian baik langsung maupun tidak langsung dari Usaha Menengah atau Usaha Besar yang memenuhi kriteria Usaha Kecil sebagaimana dimaksud dalam Undang-Undang ini.

Usaha Menengah adalah usaha ekonomi produktif yang berdiri sendiri, yang dilakukan oleh orang perorangan atau badan usaha yang bukan merupakan anak perusahaan atau cabang perusahaan yang dimiliki, dikuasai, atau menjadi bagian baik langsung maupun tidak langsung.

\subsection{Ekonomi Kreatif}

Sistem ekonomi kreatif dianggap mampu menjadi solusi untuk menghadapi tantangan ekonomi global yang diprediksi akan menggeser sistem ekonomi yang telah berjalan (Mahmud Syarif \& Ayu Azizah, 2015; Daulay, 2018). Pengembangan Ekonomi Kreatif merupakan salah satu bentuk optimisme serta luapan aspirasi dalam mendukung dan mewujudkan visi Indonesia yaitu menjadi negara maju (Daulay, 2018). Salah satu kiat untuk membangun desa yaitu dengan cara menumbuhkan jiwa entrepreneurship dan kreatifitas melalui pengembangan ekonomi dan industri kreatif (Hamid \& Ikbal, 2017). Industri kreatif mampu mengasah dan memanfaatkan bakat, kreativitas, keterampilan, yang dimiliki individu untuk membuka lapangan kerja baru (Avianto, 2017; Santosa, 2020). Ekonomi kreatif menjadi salah satu peluang maupun solusi di tengah keadaan yang serba tak jelas ini. Konsep ekonomi kreatif memiliki perbedaan dengan konsep ekonomi konvensional (Sulistyo, 2010). Menurut Santosa (2020), terdapat beberapa faktor pembeda, faktor yang dimaksud bisa berupa bentuk kreatif yang bersumber dari pengemasan, pemasaran, promosi, hingga desain produk atau jasa.

\section{Metode Penelitian}

Objek dan Lokasi penelitian ini yaitu pada UMKM yang terdapat pada Kecamatan Pulo Ampel Kabupaten Serang Banten. Metode yang digunakan dalam penelitian ini adalah metode kualitatif, melalui proses observasi, waancara dan dokumentasi, kemudian di 
sajikan dalam bentuk data. Metode analisis data yang digunakan yaitu anaslisis SWOT. Menurut David \& Rangkuti (2014), strategis pertimbangan dari kombinasi empat faktor yaitu: (1) Strategi SO Strategi ini dibuat berdasarkan jalan pemikiran perusahaan, yaitu dengan menggunakan seluruh kekuatan untuk memanfaatkan peluang; (2) Strategi ST Ini adalah strategi untuk menggunakan kekuatan yang dimiliki perusahaan dengan cara menghindari ancaman; (3) Strategi WO Strategi ini diterapkan berdasarkan pemanfaatan peluang yang ada, dengan cara mengatasi kelemahankelemahan yang dimiliki; dan (4) Strategi WT Strategi ini didasarkan pada kegiatan yang bersifat defensive dan ditujukan untuk meminimalkan kelemahan yang ada serta menghindari ancaman. Informan yang digunakan pada penelitian ini yaitu Camat Pulo Ampel, Kepada Desa yang ada di Kecamatan Pulo Ampel, para pelaku UMKM, Akademisi, pengamat UMKM, masyarakat Kecamatan Pulo Ampel. Kegiatan penelitian dilakuka selama kurun waktu satu tahun. Berdasarkan hasil analisis SWOT diatas, maka didapatkan strategi pengembangan UMKM di Kecamatan Pulo Ampel Kabupaten Serang Banten, yang tepat adalah Strategi SO (Growth). Strategi SO merupakan strategi yang memanfaatkan kekuatan yang ada untuk meningkatkan keunggulan kompetitifnya.

\section{Hasil dan Pembahasan}

\subsection{Gambaran Karakteristik Objek Penelitian}

Berikut gambaran mengenai karakteristik objek paa penelitian ini. Usaha Mikro, Kecil, dan Menengah (UMKM) mempunyai peranan strategis dalam pembangunan ekonomi nasional. UMKM berperan dalam pertumbuhan ekonomi dan penyerapan tenaga kerja. Selain itu, UMKM juga berperan dalam pendistribusian hasil-hasil pembangunan. Keberadaan sektor Usaha Mikro, Kecil, dan Menengah bukan hanya dianggap sebagai tempat penampungan sementara bagi para pekerja yang belum masuk ke sektor formal, tetapi juga sebagai motor pertumbuhan aktivitas ekonomi. Hal ini dikarenakan jumlah penyerapan tenaga kerjanya yang demikian besar. Mengingat pengalaman yang telah dihadapi oleh Indonesia selama krisis ekonomi, kiranya tidak berlebihan apabila pengembangan sektor swasta difokuskan pada UMKM.

\subsection{Analisis Data}

Kecamatan Pulau Ampel merupakan daerah kecamatan bagian dari wilayah Kabupaten Serang Provinsi Banten.Dimana Kecamatan Pulo Ampel terletak di pesisir pantai utara pulau jawa yang memiliki beberapa desa diantaranya: Argawana, Banyuwangi, Gedung Soka, Mangunreja, Margasari, Pulo Ampel, Pulau Panjang, Salira, dan Sumuranja.Kecamatan Pulau Ampel memiliki potensi produk Usaha Mikro Kecil Menengah (UMKM) yang perlu untuk di kembangkan, mulai dari hasil perkebunan, perikanan, pertanian, kerajinan tangan, peternakan, makanan, dan lain sebagainya.Namun selama ini masyarakat Kecamatan Pulo Ampel mulai aparat kecamatan,aparat desa, para pelaku Usaha Mikro Kecil Menengah (UMKM),dan lain sebagainya belum bisa mengembangkan produk hasil olahan mereka, belum bisa menciptakan produk khas lokal yang terbentuk melalui produk-produk Usaha Mikro Kecil Menengah (UMKM) mereka.Hal ini menyebabkan Kecamatan Pulo Ampel mengalami ketertinggalan dalam 
pengembangan Usaha Mikro Kecil Menengah (UMKM) dengan Kecamatan-kecamatan yang ada di Kabupaten Serang.

\section{Tabel 1}

Daftar Nama Produk Hasil UMKM Kecamatan Puloampel

\begin{tabular}{|l|l|l|l|}
\hline No. & \multicolumn{1}{|c|}{ Nama Desa } & \multicolumn{1}{|c|}{ Hasil UMKM } & \multicolumn{1}{c|}{ Keterangan } \\
\hline 1 & Argawana & Keripik pisang & Industri Produktif \\
\hline 2 & Banyuwangi & Debontot, olahan makanan dari ikan & Industri Produktif \\
\hline 3. & Gedung soka & Kerajinan Gerabah, & Industri Kreatif \\
\hline 4. & Mangunreja & Kue Gipang, Kerupuk Udang & Industri Produktif \\
\hline 5 & Margasari & Emping, Kerupuk Ikan Payus & Industri Produktif \\
\hline 6. & Pulo Ampel & Tempe \& Tahu, olahan ikan asin & Industri Produktif \\
\hline 7 & Pulau Panjang & Dola-dola rumput laut & Industri Produktif \\
\hline 8 & Salira & Kerajinan Kulit kerang, Bonsai Kelapa & Industri Kreatif \\
\hline 9. & Sumuranja & Ranginang Beras Ketan & Industri Produktif \\
\hline
\end{tabular}

Sumber: Data Kecamatan Pulo Ampel Serang 2020

Permasalahan Usaha Mikro Kecil Menengah (UMKM) berbasis ekonomi kreatif pada umumnya terletak pada : sumber daya manusia, modal, pemasaran dan penguasan teknologi informasi, masih banyak masyarakat Kecamatan Pulo Ampel yang belum mau menjadi wirausaha, belum adanya Badan Usaha Milik Desa (BUMDES) di setiap desa yang ada di Kecamatan Pulo Ampel yang mampu mengolah, menampung dan memasarkan produk hasil olahan Usaha Mikro Kecil Menengah (UMKM) di Kecamatan Pulo Ampel.Gambaran kondisi potensi Usaha Mikro Kecil Menengah (UMKM) yang ada di Kecamatan Pulo Ampel berbasis ekonomi kreatif pada saat ini, dilihat dari peluang pemberdayaan dari waktu ke waktu, dari tempat ke tempat, dan dari sektor ke sektor belum mengindikasikan besarnya harapan pada kelompok usaha tersebut untuk mendukung tumbuhnya sistem perekonomian yang berkeadilan. Hal ini juga mengakibatkan Usaha Mirko Kecil Menengah (UMKM) berbasis ekonomi kreatif belum mampu memberikan suatu ciri khas khusus bagi Kecamatan Pulo Ampel dikenal oleh masyarakat umum baik di dalam maupun luar kecamatan Pulo Ampel itu sendiri.

\subsection{Hasil Wawancara dengan Informan}

Profil Informan Informan penelitian berjumlah 20 informan UMKM Industri kreatif dan Insutri Produktif yang ada di Kecamatan Pulo Ampel, Pihak Akademisi, dan pihak Pemerintah Desa dan Kecamatan. Pelaku UMKM kreatif berjenis kelamin laki-laki sejumlah 12 orang atau 37,5\% dari total informan dan pelaku UMKM berjenis kelamin perempuan sebesar 20 orang atau 62,5\% dari total informan UMKM. Informan paling dominan adalah yang berusia 30-40 tahun sebanyak 10 orang atau 50\% dari total responden yang diteliti. Dilihat dari jumlah tenaga kerja, jenis usaha mereka tergolong jenis usaha skala mikro dengan jumlah tenaga kerja yang berkisar 1-5 orang.

Usaha Mikro Kecil dan Menengah (UMKM) yang di teliti adalah industri kecil produktif yang mengolah bahan mentah menjadi barang jadi, sebagian besar dari olahan hasil laut seperti: Dola-dola dari rumput laut, Debontot dari olahan ikan laut, kerupuk 
payus olahan dari ikan laut, dan ada industri kreatif seperti kerajinan dari kulit kerang, kerajinan gerabah dan kerajinan Bonsai dari kelapa muda.

\subsubsection{Permasalahan umum UMKM Kreatif di Kecamatan Pulo Ampel}

Salah satu informan selaku pemerintah dari Kecamatan Pulo Ampel, Camat Pulo Ampel (Bapak Camat Pulo Ampel) mengatakan bahwa:

Kerjasama antar UMKM masih kurang dan perlu ditingkatkan. Bagi usaha mikro biasanya permodalan, masih banyak yang kurang sehingga mengakibatkan produksi mereka terbatas. Bagi usaha mikro juga tenaga kerja masih dari keluarga saja, sedangkan usaha kecil biasanya sudah ada karyawan. Pemasaran produk masih bersipat konvensional, keliling dan menunggu pesanan.

Pernyataan tersebut menunjukkan bahwa UMKM produktif dan kreatif di Kecamatan Pulo Ampel, memiliki kemampuan yang terbatas serta mengalami permasalahan dalam pengembangan usahanya. Permasalahan UMKM khususnya bagi usaha mikro masih berkutat pada modal. Permodalan yang terbatas dapat menyebabkan kapasitas produksi mereka terbatas. Tenaga kerja bagi UMKM juga kebanyakan masih berasal dari keluarga sendiri, sehingga kemampuan dan jam kerjanya pun masih sekedarnya. Selain itu, pemasaran yang dilakukan oleh UMKM pemula masih sederhana dan hanya mengandalkan pasenan

Pegawai Dinas Koperasi \& UMKM Kabupaten Serang, mengatakan:

Pengembangan Usaha Mikro Kecil \& Menengah (UMKM) di Kecamatan Pulo Ampel belum optimal, karena beberapa faktor diantaranya: sumber daya manusia, permodalan, pemasaran, dan lain sebagainya, padahal potensi UMKM yang ada di Kecamatan Pulo Ampel luar biasa banyak.

Pernyataan tersebut menunjukan bahwa UMKM berbasis ekonomi kreatif dan produktif di Kecamatan Pulo Ampel belum bisa berkembang dengan optimal karena di sebabkan beberapa faktor diantaranay : belum di terapkan strategi pengembangan, faktor sumber daya manusia di latarbelakangi faktor pendidikan, pemasalahan modal usaha, dan pemasaran, sehingga perlu adanya penerapan strategi pengembangan UMKM, bekerjasama dengan lembaga keuangan yang bisa memberikan modal usaha dengan bunga yang rendah, adanya pelatihan pemasaran produk terutama pemasaran secara online.

Pihak Akademisi warga Pulo Ampel (Suflani., ST., MT), mengatakan:

Selama ini para pelaku Usaha Mikro Kecil \& Menengah (UMKM) yang ada di Kecamatan Pulo Ampel, kualitas sumber daya manusianya masih kurang baik, dalam proses produksi maupun proses pemasaran.

Pernyataan tersebut menunjukan bahwa kualitas sumber daya manusia para pelaku UMKM masih kurang, karena latabelakang pendidikan yang masih minim, untuk itu perlu adanya pelatihan dan pengembangan sumber daya manusia para pelaku UMKM di Kecamtan Pulo Ampel, terutama dalam proses pembuatan produk dan pemasaranya.

Pelaku Usaha Dola-Dola Rumput laut mengatakan:

Masih kurang kerjasama para pelaku Usaha Mikro Kecil dan Menengah (UMKM) di Kecamatan Pulo Ampel dengan Dinas Koperasi \& UMKM Kabupaten Serang, Aparat 
Kecmatan Pulo Ampel, Aparat Desa yang ada di Kecamatan Pulo Ampel dan masyarkat sekitarnya dalam pengembangan UMKM.

Pernyataan tersebut menunjukan bahwa perlu adanya kerjasama antara para pelaku Usaha Mirko Kecil dan Menengah (UMKM) yang ada di Kecamatan Pulo Ampel dalam proses pengembangan UMKM berbasis Ekonimi kreatif dan produktif dalam membantu meningkatkan perekonomian masyarakat yang ada di Kecamatan Pulo Ampel itu sendiri.

\subsubsection{Permasalahan Modal}

Permasalahan modal merupakan masalah yang klasik bagi UMKM. Para pelaku UMKM kreatif di Kecamatan Pulo Ampel, mayoritas mengalami keterbatasan finansial dalam permodalan. Salah satu informan pelaku UMKM kreatif, Ibu Nani Setiyaningsih mengungkapkan:

"Kebanyakan para pelaku UMKM di Kecamatan Pulo Ampel, membutuhkan tambahan modal, tetapi banyak pihak bank atau lembaga keuangan yang mempersulit dalam proses peminjaman ke bank tersebut"

Pernyataan tersebut diatas menunjukan belum adanya kerjasama antara para pelaku UMKM dengan lembaga keuangan terkait permodalan usaha, sehingga perlu adanya kerjasama dengan lembaga keuangan terkait pinjaman modal usaha dengan bunga rendah bagi para pelaku UMKM yang ada di Kecamatan Pulo Ampel, perlu adanya BUMDES atau Koperasi Unit Desa.

\subsubsection{Bahan Baku dan Peralatan Produksi}

Para pelaku UMKM berbasis ekonomi kreatif di Kecamatan Pulo Ampel juga mengungkapkan kendala dalam perolehan bahan baku dan peralatan proses produksi.

Para pelaku Usaha Mikro Kecil \& Menengah (UMKM) yang ada di Kecamatan Pulo Ampel sering mengalami kesulitan bahan baku untuk memproduksi produk olahan dan belum adanya alat yang praktis dan ekonomi dalam memproduksi sebuah produk. Pernyataan diatas menunjukan bahwa para pelaku UMKM sering mengalami masalah bahan baku, terutama bahan baku dari hasil ikan laut, kalau kondisi ombak lagi pasang ikan susah di cari, dimana sebagian usaha mereka berbahan baku ikan olahan, sedangkan untuk alat produksi selama ini masih sederhana, belum menggunakan sebuah alat atau mesin yang bisa membantu secara ekonomis dan praktis dalam proses memproduksi sebuah produk.

\subsubsection{Media Pemasaran Terbatas}

Masalah pemasaran yang dihadapi oleh para pelaku UMKM kreatif di Kecamatan Pulo Ampel yaitu tidak adanya tempat aktualisasi. Hal ini diungkapkan oleh pihak akademisi pengamat UMKM, Suflani. ST., MT berikut:

Masalah yang dihadapi yaitu pemasaran produk, tidak adanya tempat aktualisasi sehingga masih banyak orang yang belum mengenal produk hasil olahan UMKM Kecamatan Pulo Ampel, baik industri produktif maupun industri kreatifnya.

Di perlukan adanya pembentukan sentra industri kreatif dan industri produktif di Kecamatan Pulo Ampel untuk mendukung pengembangan industri kreatif dan insutri produktif bagi para pelaku Usaha Mikro Kecil dan Menengah yang ada di Kecamatan 
Pulo Ampel dengan produk hasil olahan mereka bisa di kenal bukan hanya di sekitar Kabupaten Serang tetapi di harapkan bisa dikenal di luar Kabupaten Serang dan sekitarnya.

\subsubsection{Tenaga Kerja}

Permasalahan ketenagakerjaan yang dialami oleh UMKM berbasis ekonomi kreatif di Kecamatan Pulo Ampel adalah keterampilan/skill individu. Kepala Desa Pulo Ampel dan Kepala Desa Sumuranja menuturkan:

Kualitas sumber daya manusia para pelaku Usaha Mikro Kecil dan Menengah (UMKM) di Kecamatan Pulo Ampel masih kurang, selama ini mereka otodidak dalam menjalankan usahanya, baik dalam proses produksi dan pemasarannya.

Banyak pelaku UMKM mengeluhkan tentang kurang berkualitasnya sumber daya manusia

karena sebagian besar dari tenaga kerja mereka berlatar belakang pendidikan yang rendah sehinggadiperlukan upaya ekstra untuk membina secara lebih baik dalam proses memproduksi produk dan pemasaran produknya.

\subsubsection{HAKI (Hak Atas Kekayaan Intelektual)}

Pengertian Hak Atas Kekayaan Intelektual (HAKI) secara umum adalah hak-hak yang secara hukum diberikan untuk melindungi nilai ekonomi bagi usaha-usaha kreatif. Jenisjenis perlindungan terhadap HAKI meliputi patent (patents), hak cipta (copy rights), merek (trademarks), desain industri (industrial designs), rahasia dagang (trade secrets), indikasi geografis (geographical indications), desain tataletak sirkuit terpadu (layout design of integrated circuits), dan perlindungan varietas tanaman (plant variety protection). UMKM kreatif di kota Semarang masih belum sepenuhnya memiliki Hak Atas Kekayaan Intelektual (HAKI).

\subsubsection{Solusi untuk kemajuan UMKM berbasis ekonomi kreatif Kecamatan Pulo Ampel.}

UMKM berbasis ekonomi kreatif memerlukan kerja sama dari berbagai pihak untuk mencapai kemajuan di dunia usaha. Tidak hanya pemerintah dan pelaku UMKM itu sendiri, tetapi juga masyarakat perlu turut serta mengembangkannya. Upaya tersebut dapat tercermin melalui penggunaan produk lokal dan kampanye untuk senantiasa menggunakan produk buatan anak bangsa. Selain itu, kerjasama antar individu juga diperlukan untuk mengindari terciptanya iklim persaingan yang tidak sehat. Pihak pemerintah mengatakan untuk melakukan pengembangan UMKM kreatif di Kecamatan Pulo Ampel harus dilakukan antisipasi ke depan yang sifatnya kontinyu. Seperti penuturan Staff Dinas Koperasi dan UMKM Kabupaten Serang berikut:

UMKM berbasis ekonomi kreatif harus senantiasa menjaga mutu serta meningkatkan kreatifitas dan inovasinya dalam menghasilkan karya-karya baru. Peningkatan kreatifitas bagi para pelaku UMKM dapat dilakukan melalui serangkaian proses pelatihan dari pemerintah seperti manajemen pengelolaan usaha, manajemen pemasaran, keuangan, dan lain sebagainya. Hal tersebut juga merupakan salah satu senjata yang ampuh untuk terus mengembangkan potensi budaya lokal di Kecamatan Pulo 
Ampel. Peran pemerintah secara penuh tentunya sangat diperlukan untuk membantu proses pengembangan UMKM kreatif di Kecamatan Pulo Ampel. Solusi untuk kemajuan UMKM kreatif di Kecamatan Pulo Ampel juga diperoleh melalui pendapat Wiwik Budiawan, informan selaku akademisi pengamat UMKM yang menyampaikan bahwa:

Solusinya untuk UMKM kreatif sendiri yaitu: yang pertama jelas pemetaan dulu, pemetaan atau identifikasi kita itu punya industri kreatif seperti apa. Setelah itu, kita memilih mana yang bener-bener ciri khas yang pengen dikembangin, bagaimana mengenalkan produk itu di luar Kecamatan Pulo Ampel. Setelah sudah terkenal, baru kan kita membentuk suatu sentra industri. Setelah itu memberdayakan SDM nya untuk meningkatkan kualitas produk. Lalu kita memperkenalkan di level nasional.

Pernyataan diatas menyebutkan bahwa solusi yang pertama bagi kemajuan UMKM yaitu perlu dilakukan pemetaan industri kreatif dan industri produktif yang ada di Kecamatan Pulo Ampel. Pemetaan disini bisa berupa pembagian cluster Usaha Mikro Kecil dan Menengah (UMKM) seperti UMKM Industri Ekonomi Produktif dan UMKM Industri Ekonomi Kreatif.Setelah itu, memilih produk apa yang menjadi ciri khas Kecamatan Pulo Ampel serta layak untuk dikembangkan dan bagaimana cara mengenalkan produk kreatif tersebut ke luar daerah. Setelah sudah terkenal, baru dilakukan pembentukan sentra industri kreatif dan Industri Produktif kemudian memberdayakan sumber daya manusia agar kualitas produk tetap terjaga. Langkah terakhir yang dilakukan yaitu dengan memperkenalkan produk kreatif dan produktif UMKM lokal ke level nasional.

\section{Tabel 2}

Matriks SWOT

\begin{tabular}{|c|c|c|}
\hline \multirow{11}{*}{ FaktorEksternal } & \multirow{11}{*}{$\begin{array}{l}\text { Strength (S) } \\
\text { 1. Modal milik sendiri } \\
\text { 2. Bahan Baku Mudah di } \\
\text { peroleh } \\
\text { 3. Kualitas bahan baku } \\
\text { konsisten } \\
\text { 4. Tenaga kerja keluarga } \\
\text { 5. Menerima Pesanan } \\
\text { 6. Biaya produksi terjangkau } \\
\text { 7. Penjualan konvensional } \\
\text { 8. Memiliki alat transportasi } \\
\text { 9. Memiliki gudang } \\
\text { 10. Memiliki kemasan baik\& } \\
\text { menarik }\end{array}$} & \multirow{11}{*}{$\begin{array}{l}\text { Weakness (W) } \\
\text { 1. Tidak memiliki akses } \\
\text { pada lembaga keuangan } \\
\text { 2. Tidak memiliki } \\
\text { pengalaman dalam } \\
\text { meminjam dana } \\
\text { 3. Tidak memiliki aset buat } \\
\text { jaminan } \\
\text { 4. Tidak dipisahkan } \\
\text { keuangan usaha dan } \\
\text { pribadi } \\
\text { 5. Peralatan produksi masih } \\
\text { sederhana } \\
\text { 6. Tidak memiliki merek } \\
\text { yang di patenkan } \\
\text { 7. Tidak memiliki tim } \\
\text { pemasaran } \\
\text { 8. Tiak memilki informasi } \\
\text { terkait pemasaran }\end{array}$} \\
\hline & & \\
\hline & & \\
\hline & & \\
\hline & & \\
\hline & & \\
\hline & & \\
\hline & & \\
\hline & & \\
\hline & & \\
\hline & & \\
\hline Opportunity (O) & Strategi SO $($ Growth $)$ & Strategi WO (Stability) \\
\hline $\begin{array}{l}\text { 1. Mengtahui } \\
\text { kredit }\end{array}$ & $\begin{array}{ll}\text { 1. } & \begin{array}{l}\text { Mengikuti } \\
\text { pengembangan }\end{array} \\
\text { UMKM }\end{array}$ & $\begin{array}{l}\text { 1. Mengikuti pelatihan } \\
\text { penigkatan } \\
\text { kualitas }\end{array}$ \\
\hline
\end{tabular}




\begin{tabular}{|c|c|c|}
\hline $\begin{array}{l}\text { 2. Mencari pembelian bahan } \\
\text { baku yang lebih baik. } \\
\text { 3. Mencari pasar baru atau } \\
\text { peluang baru } \\
\text { 4. Mengikuti pelatihan } \\
\text { peningkatan keahlian } \\
\text { tenaga kerja } \\
\text { 5. Ikut serta dalam kebijakan } \\
\text { dan kegiatan UMKM } \\
\text { 6. Mengikuti sistem } \\
\text { pemasaran dari kelompok } \\
\text { yang diikuti pembinaan } \\
\text { 7. Ikut dalam pinas } \\
\text { program kemitraan } \\
\text { 8. Adanya peran Dinas } \\
\text { Koperasi \& UMKM } \\
\text { Serang }\end{array}$ & $\begin{array}{l}\text { kredit lunak utnuk } \\
\text { menambah modal usaha } \\
\text { 2. Melakukasn kerjasama } \\
\text { antara pelaku UMKM } \\
\text { dengan Dinas Koperasi \& } \\
\text { UMKM } \\
\text { Kabupaten.Serang. } \\
\text { 3. Menjaga hubungan baik } \\
\text { dengan karyawan dan } \\
\text { memberikan pelatihan } \\
\text { 4. Melakukan } \\
\text { pengembangan produk } \\
\text { dengan menjaga kualitas } \\
\text { produk } \\
\text { Melakukan pemasaran dan } \\
\text { promosi online } \\
\text { 6. Mengikuti program } \\
\text { pengembangan UMKM } \\
\text { baik oleh pemerintah atau } \\
\text { swasta } \\
\text { 7. Menjaga aset dengan baik }\end{array}$ & $\begin{array}{l}\text { produk dan tenaga } \\
\text { pembukuan keuangan } \\
\text { 2. Mengikuti program } \\
\text { pengembangan UMKM } \\
\text { kredit rendah untuk } \\
\text { menambah modal usaha } \\
\text { 3. Melakukan pembaruan } \\
\text { alat produksi } \\
\text { 4. Melakukan pembelian } \\
\text { secara kredit } \\
\text { 5. Melakukan promosi dan } \\
\text { pemasaran online } \\
\text { 6. Mencari pasar baru dan } \\
\text { penyedia bahan baku } \\
\text { yang lebih besar } \\
\text { 7. Mengikuti program } \\
\text { pengembangan UMKM } \\
\text { yang diadakan baik oleh } \\
\text { pemerintah \& swasta }\end{array}$ \\
\hline $\begin{array}{l}\text { Threat }(\mathbf{T}) \\
\text { 1. Tidak ikut dalam } \\
\text { pendanaan bunga lunak } \\
\text { yang diberikan oleh } \\
\text { pemerintah. } \\
\text { 2. Tidak ada pelatihan } \\
\text { pengembangan produk } \\
\text { 3. Tidak ada pelatihan } \\
\text { teknologi informasi } \\
\text { terkait pemasaran online } \\
\text { 4. Tidak ada kerjasama para } \\
\text { pelaku UMKM dengan } \\
\text { Dinas Koperasi \& } \\
\text { UMKM Kabupaten } \\
\text { Serang. } \\
\text { 5. Kualitas SDM masih } \\
\text { minim. } \\
\text { 6. Kondisi pandemi coovid- } \\
\text { 19, bisa menghambat } \\
\text { perkembangan usaha }\end{array}$ & $\begin{array}{l}\text { Strategi ST (Diversification) } \\
\text { 1. Mengikuti program } \\
\text { kemitraan UMKM kredit } \\
\text { lunak untuk menambah } \\
\text { modal usaha } \\
\text { 2. Menjaga hubungan baik } \\
\text { dengan penyedia bahan } \\
\text { baku } \\
\text { 3. Menjaga hubungan baik } \\
\text { dengan karyawan } \\
\text { 4. Menjaga kualitas produk } \\
\text { yang di legalkan } \\
\text { 5. Melakukan pembaruan } \\
\text { alat produk yang lebih } \\
\text { canggih dan efisien } \\
\text { 6. Melakukan promosi } \\
\text { terhadap industri yang } \\
\text { lebih besar } \\
\text { 7. Menjaga aset dengan baik } \\
\text { 8. Memperhatikan kondisi } \\
\text { pasar. }\end{array}$ & $\begin{array}{l}\text { Strategt WT (Defend) } \\
\text { 1. Mengikuti program } \\
\text { pengembangan umkm } \\
\text { dengan bunga lunak untuk } \\
\text { menambah modal usaha } \\
\text { 2. Mengikuti pelatihan } \\
\text { peningkatan kualitas } \\
\text { tenaga kerja bagian } \\
\text { pembukuan keuangan } \\
\text { 3. Melakukan pembaruan } \\
\text { alat produksi yang } \\
\text { canggih \& efisien } \\
\text { 4. Melakukan diferensiasi } \\
\text { produk dan mematenkan } \\
\text { produk promosi dan } \\
\text { 5. Melakukan promonaran } \\
\text { memberikan pembayaran } \\
\text { kredit promosi } \\
\text { 6. Melakukan yandis } \\
\text { terhadap industri yang } \\
\text { lebih besar } \\
\text { 7. Memperhatikan kondisi } \\
\text { pasar. }\end{array}$ \\
\hline
\end{tabular}


Berdasarkan hasil analisis SWOT diatas, maka didapatkan strategi pengembangan UMKM di Kecamatan Puloampel Kabupaten Serang Banten, yang tepat adalah Strategi SO (Growth). Strategi SO (Growth) merupakan strategi yang memanfaatkan kekuatan yang ada untuk meningkatkan keunggulan kompetitifnya.Melalui strategi SO (Growth) tersebut, UMKM yang ada di Kecamatan Puloampel Serang Banten, di harapkan menjalankan ekpansi pasar, memperbesar pertumbuhan produksi dan pengupayakan kemajuan teknologi secara maksimal.Strategi SO (Growth) yang tertuang dalam matriks SWOT, menunjukan bahwa terdapat 7 (tujuh) strategi yang dapat dilakukan untuk mengembangkan UMKM berbasis ekonomi kreatif di Kecamatan Puloampel diantaranya:

1. Mengikuti program pengembangan UMKM kredit lunak utnuk menambah modal usaha

2. Melakukasn kerjasama antara pelaku UMKM dengan Dinas Koperasi \& UMKM Kabupaten.Serang.

3. Menjaga hubungan baik dengan karyawan dan memberikan pelatihan

4. Melakukan pengembangan produk dengan menjaga kualitas produk

5. Melakukan pemasaran dan promosi online

6. Mengikuti program pengembangan UMKM baik oleh pemerintah atau swasta

7. Menjaga aset dengan baik.

\section{Simpulan}

UMKM kreatif belum mampu memberikan predikat khusus bagi Kecamatan Pulo Ampel, karena mereka memiliki kemampuan yang terbatas serta mengalami permasalahan dalam pengembangan usahanya. Beberapa permasalahan yang dihadapi UMKM kreatif Kecamatan Puloampel antara lain permasalahan permodalan yang terbatas, bahan baku dan penggunaan peralatan produksi yang sederhana, media pemasaran terbatas karena belum adanya sentra UMKM, biaya transaksi yang cukup banyak, tenaga kerja yang kurang terampil, dan masalah pendaftaran hak cipta mereka. Solusi dari pihak pemerintah untuk kemajuan UMKM kreatif di Kecamatan Pulo Ampel yaitu dengan dilakukan antisipasi ke depan yang sifatnya kontinyu. Adapun solusi dari pihak akademisi pengamat UMKM antara lain perlu dilakukan pemetaan industri kreatif yang ada di Kecamatan Pulo Ampel. Pemetaan disini bisa berupa pembagian cluster seperti: UMKM industri kreatif dan produktif dan sebagainya, memilih produk apa yang menjadi ciri khas Kecamatan Pulo Ampel, serta layak untuk dikembangkan, bagaimana cara mengenalkan produk kreatif tersebut ke luar daerah, setelah sudah terkenal baru dilakukan pembentukan sentra industri kreatif, memberdayakan sumber daya manusia agar kualitas produk tetap terjaga, memperkenalkan dilevel nasional.

Untuk penelitian selanjutnya diharapkan dapat melibatkan lebih banyak pelaku UMKM produktif dan kreatif yang ada di Kecamatan Pulo Ampel. Selain itu, sentra industri kreatif di Kecamatn Pulo Ampel perlu dibentuk sebagai wadah bagi mereka sehingga memudahkan pemantauan perkembangan UMKM kreatif di Kecamatan Pulo Ampel. 


\section{Referensi}

Alfrian, G. R., \& Pitaloka, E. (2020), Strategi Usaha Mikro, Kecil, dan Menengah (UMKM) bertahan pada kondisi pandemik covid 19 di Indonesia. In Prosiding Seminar Nasional Terapan Riset Inovatif (SENTRINOV), Vol. 6 No. 2, pp. 139-146.

Amri, A. (2020), Dampak covid-19 terhadap UMKM di Indonesia, BRAND Jurnal Ilmiah Manajemen Pemasaran, Vol. 2 No. 1, pp. 123-131.

Avianto, B. N. (2017), Analisis Pengembangan Home Industri Unggulan Kaos Etnik Khas Cirebon di Kecamatan Plered Kabupaten Cirebon, Syntax Literate; Jurnal Ilmiah Indonesia, Vol. 2 No. 5, pp. 48-57.

Daulay, Z. A. A. (2018), Strategi Pengembangan Ekonomi Kreatif Dengan Metode Triple Helix (Studi Pada UMKM Kreatif di Kota Medan), TANSIQ: Jurnal Manajemen Dan Bisnis Islam, Vol. 1 No. 1. pp. 170-190.

David \& Rangkuti, F. (2014), Manajemen Strategi, Edisi Sepuluh, Salemba Empat, Jakarta.

Hamid, R. S., \& Ikbal, M. (2017), Analisis Dampak Kepercayaan pada Penggunaan Media Pemasaran Online (E-Commerce) yang Diadopsi oleh UMKM: Perspektif Model DeLone \& McLean, Jurnal Manajemen Teknologi, Vol. 16 No. 3, pp. 310337.

Hamid, R. S., \& Ikbal, M. (2017), Pemberdayaan Pemuda Melalui Program Remaja Pintar Berbasis Ekonomi Kreatif Desa Lera Kecamatan Wotu Kabupaten Luwu Timur, RESONA: Jurnal Ilmiah Pengabdian Masyarakat, Vol. 1 No. 1. pp. 39-45.

Pakpahan, A. K. (2020), Covid-19 dan implikasi bagi usaha mikro, kecil, dan menengah, Jurnal Ilmiah Hubungan Internasional, (Edisi Khusus), pp. 59-64.

Santosa, A. (2020), Pengembangan Ekonomi Kreatif Industri Kecil Menengah Kota Serang Di Masa Pandemi Covid-19, Syntax Literate; Jurnal Ilmiah Indonesia, Vol. 5 No. 11, pp. 1257-1272.

Sugiyanto, S., Putri, A., \& Kartolo, R. (2021), Potensi Kekayaan Intektual Pada Pemberdayaan Umkm Dan Koperasi Kota Tangerang Selatan, Proceedings Universitas Pamulang, Vol. 1 No. 1. pp. 502-520.

Sulistyo, S. (2010). Pengembangan USAha Kecil dan Menengah dengan Basis Ekonomi Kerakyatan di Kabupaten Malang. Jurnal Ekonomi Modernisasi, Vol. 6 No. 1, pp. $58-73$.

Supardi, S., Nugraha, N. M., Susanti, N., Sumantri, M. B. A., \& Mukhlis, T. I. (2021), PELUANG DAN PERUBAHAN CARA BERPIKIR SAAT PANDEMIK (Pengabdian Kepada UMKM Binaan Kadin Provinsi Jawa Barat), Jurnal Pengabdian Dharma Laksana, Vol. 3 No. 2, 162-168.

Syarif, M., Azizah, A., \& Priyatna, A. (2015), Analisis perkembangan dan peran industri kreatif untuk menghadapi tantangan MEA 2015, SNIT 2015, Vol. 1 No. 1, pp. $27-$ 30 .

Undang-Undang nomor 20 tahun 2008 tentang Usaha Mikro, Kecil, dan Menengah, UMKM 